\title{
STRUKTUR KEPEMILIKAN DAN STRUKTUR DEWAN PERUSAHAAN
}

\author{
Ella Budiarti \\ Chorry Sulistyowati \\ ella-b-11@feb.unair.ac.id \\ Departemen Manajemen Fakultas Ekonomi dan Bisnis Universitas Airlangga
}

\begin{abstract}
This study aims to determine the effect of ownership structure and corporate board structure. This study use two-tiers board system and use secondary data from non-financial firm which fulfill the requirement and listing in Indonesia Stock Exchange from 2010-2013. The analysis technique used a quantitative method with multiple linear regression. The object of research used in this research are non financial companies listed on the Stock Exchange in 2010 to 2013 the number of samples obtained some 191 samples. The results obtained are foreign ownership and managerial ownership negative significant with board size. And managerial dan government ownership negative significant with independent commissioners but foreign ownership has positive significant. The results emphasize that different ownership has behavior and preferences for corporate governance practices especially board structures.
\end{abstract}

\section{Keyword : ownership structure, corporate board structure, two-tiers board system}

\section{Pendahuluan}

Corporate governance menjadi hal penting, terutama saat terjadi krisis ekonomi global yang melanda hampir di seluruh dunia. Sistem corporate governance dapat mempengaruhi pembentukan sistem tata kelola perusahaan di negara-negara yang berbeda, seperti peraturan, struktur kepemilikan, budaya dan lingkungan ekonomi. Mekanisme dalam penerapan corporate governance merupakan suatu cara yang dapat digunakan untuk menyelesaikan konflik keagenan (Destriana, 2011). Perusahaan go public di Indonesia strukturnya dicirikan dengan pemisahan antara pemilik dan pengelola. Pemegang saham (principals) akan menyewa orang lain atau manajer (agents) untuk mengelola perusahaan, yang kemudian melahirkan apa yang disebut dengan hubungan principals-agents. "Hubungan principal-agent dapat memunculkan agency problem dalam perusahaan" (Jensen dan Meckling, 1976). Agency problem yang tinggi berada pada perusahaan atau Negara yang ditandai karakteristik ketidakpastian yang tinggi pula seperti pertumbuhan industri yang tinggi, emerging market dan Negara berkembang (Munisi dkk.,2014). Indonesia termasuk negara emerging market, yang berarti secara internasional Indonesia diakui sebagai negara dengan potensi ekonomi yang patut diperhitungkan. 


\section{Ella Budiarti \\ Chorry Sulistyawati}

Pada umumnya pemegang saham atau pemilik menginginkan agar perusahaan bisa tetap eksis dan substain dalam persaingan industri dan terhindar dari agency problem yang tinggi, sehingga pemegang saham memilih agen yang dapat mengkoordinasikan perusahaan dengan tata kelola yang baik. Jansen (1993) menjelaskan bahwa struktur dewan perusahaan dianggap sebagai instrument pengawasan yang baik bagi para pemegang saham. Peranan dewan sangat penting untuk memonitor manajemen agar sesuai dengan standar yang berlaku dan mencegah terjadinya praktek kecurangan dan meningkatkan nilai perusahaan. Jensen dan Meckling (1976), mengungkapkan bahwa ukuran dewan direksi yang lebih besar dapat mengurangi keefektifan pengawasan karena komunikasi dan koordinasi serta kemampuan dewan dalam mengendalikan manajemen dapat menimbulkan masalah keagenan. Fama dan Jensen (1983) menyatakan bahwa outside director akan lebih efektif dalam memonitor manajemen selain itu outsider juga lebih banyak memberikan expert knowledge dan nilai tambah bagi perusahaan. Corporate board structure di Indonesia menganut two-tier system yang dikarakteristikkan sebagai management board dan supervisory board. Dalam sistem dua tingkat (two-tiers), Pemegang saham akan menunjuk sekelompok pengelola operasi perusahaan (management) dan juga pengawas dan penasihat manajemen yang disebut komisaris (Commissioners). Keduanya bertanggug jawab, diangkat dan di berhentikan oleh RUPS (Rapat Umum Pemegang Saham). Struktur dewan perusahaan di Indonesia terdiri dari dewan direksi, dewan komisaris, dan komisaris independen yang merupakan pihak yang melakukan monitoring secara independen dan tidak memiliki hubungan sama sekali dengan perusahaan dan pemegang saham.

Struktur dewan perusahaan merupakan hasil dari menyeimbangkan kepentingan dari stakeholder yang berbeda termasuk pemilik. Artinya pemilik yag berbeda mungkin menunjukkan ciri-ciri yang berbeda dari perilaku dan pilihan untuk tata kelola perusahaan yang cenderung mempengaruhi struktur dewan (Munisi dkk.,2014). Dalam penelitian ini membahas tentang pengaruh struktur kepemilikan terhadap struktur dewan perusahaan yang diukur dengan Ukuran dewan direksi (BOARD SIZE) dan Komisaris Independen (INDEPENDENCE). Peneltian ini menggunakan sampel perusahaan non keuangan yang terdaftar pada Bursa Efek Indonesia pada tahun 2010-2013.

\section{Landasan Teori dan Pengembangan Hipotesis}

\subsection{Landasan Teori}

\subsubsection{Teori Keagenan ( Agency theory )}

Teori keagenan adalah hubungan atau kontrak antara principal (pemilik) dan agent (pengelola). Jensen dan Meckling (1976) mengungkapkan bahwa hubungan principalagent dapat memunculkan agency problem dalam perusahaan. Pemegang saham 


\section{Jurnal Manajemen Teori dan Terapan \\ Tahun 7. No. 3, Desember 2014}

(principals) akan menyewa orang lain atau manajer (agents) untuk mengelola perusahaan. Pemisahan antara pemilik dengan pengelolah dapat terjadi perbedaan kepentingan diantara dua belah pihak. Pihak pengelolah dapat bertindak sesuatu yang dapat menguntungkan dirinya sendiri dalam mengelolah perusahaan dan mengapaikan kepentingan pemilik, hal tersebut dapat memicu terjadinya agency problem.

Menurut Onetto (2007) "antara dewan dan pemegang saham di mana dewan akan memainkan peran sebagai agen dan pemegang saham sebagai principal". Pemegang saham berkontribusi dalam modal dan mempertahankan kepemilikan. Manajemen membuat keputusan sesuai dengan operasional perusahaan, termasuk perencanaan strategis, manajemen risiko, dan laporan keuangan. Sedangkan dewan yang mengawasi kinerja manjemen atas nama para pemegang saham, dan intervensi untuk memperbaiki inefisiensi dalam operasionalnya.

Berbagai pendekatan dilakukan untuk meminimalkan masalah keagenan salah satunya adalah pendekatan independence yang diungkapkan oleh Dalton dkk.,(2007). Kehadiran dewan yang independen dapat memonitor manajer dan memastikan bahwa kepentingan mereka tidak menyimpang dan kinerjanya lebih efektif. Peranan dewan sangat penting untuk memonitor manajemen agar sesuai dengan standar yang berlaku dan mencegah terjadinya praktek kecurangan dan meningkatkan nilai perusahaan. Jensen dan Meckling (1976), mengungkapkan bahwa ukuran dewan direksi yang lebih besar dapat mengurangi keefektifan pengawasan karena komunikasi dan koordinasi serta kemampuan dewan dalam mengendalikan manajemen dapat menimbulkan agency problem. Selain itu Fama dan Jensen (1983) menyatakan bahwa outside director akan lebih efektif dalam memonitor manajemen selain itu outsider juga lebih banyak memberikan expert knowledge dan nilai tambah bagi perusahaan

\subsubsection{Corporate Governance}

OECD (2004:11) mendefinisikan corporate governance sebagai salah satu elemen kunci dalam meningkatkan efisiensi, pertumbuhan ekonomi dan kepercayaan investor. Yang menunjukkan sekumpulan hubungan antara pihak manajemen perusahaan, dewan perusahaan dan pemegang saham dan pihak lain yang mempunyai kepentingan dengan perusahaan. Good corporate governance juga mensyaratkan adanya struktur, perangkat untuk mencapai tujuan dan pengawasan atas kinerja. Prinsip dari corporate governance yaitu fairness (keadilan). transparency (transparansi), accountability (akuntabilias), responsibility (responsibilitas), dan indepedency (independen).

\subsubsection{Struktur Dewan Perusahaan (Board Structure)}

Bennedsen (2002) mengemukakan bahwa suatu perusahaan akan mempunyai 2 motif untuk memiliki dewan perusahaan yaitu motif governance (penciptaan nilai) dan motif distributive (membatasi kepentingan pengawasan oleh pemilik). Dewan memberikan 


\section{Ella Budiarti \\ Chorry Sulistyawati}

perlindungan untuk shareholder dalam perusahaan dengan monitoring dan control (Fama dan Jensen, 1983). Jansen (1993) mengemukakan bahwa mekanisme tata kelola perusahaan dapat dilakukan secara eksternal seperti melalui pasar dan apabila tidak efektif dalam menyelesaikan masalah keagenan, maka solusi utamanya bisa ditemukan melalui internal perusahaan. Menurut Munisi., dkk (2014) bahwa struktur dewan memainkan peran sentral dalam tata kelola internal perusahaan, mereka adalah salah satu mekanisme tata kelola perusahaan yang paling penting dalam pengembangan ekonomi.

Menurut Lembaga Direksi dan Komisaris Indonesia dalam artikelnya board duties Indonesia (2011) system board yang digunakan di Indonesia adalah two-tier board system. Dalam sistem dua tingkat (two-tiers), pemegang saham akan menunjuk sekelompok pengelola operasi perusahaan (management) yang diwakili oleh direksi dan juga pengawas (supervisory) sebagai penasihat manajemen yang disebut komisaris (Commissioners). Dalam penelitian ini menggunakan variabel struktur dewan perusahaan yang digunakan adalah ukuran dewan direksi dan proporsi komisaris independen.

\subsubsection{Ukuran Dewan Direksi (Board Size)}

Ukuran dewan direksi yang kecil dapat memberikan keuntungan bagi pemegan saham dan perusahaan. Jensen dan Meckling (1976) menyatakan bahwa ukuran dewan direksi yang lebih besar dapat mengurangi keefektifan pengawasan karena komunikasi dan koordinasi serta kemampuan dewan dalam mengendalikan manajemen dapat menimbulkan masalah keagenan akibat adanya pemisahan antara manajemen dan pengendali. Lipton dan Lorch (1992) menyatakan bahwa terdapat beberapa kekurangan dalam besarnya ukuran dewan direksi. Ukuran dewan direksi yang besar akan berakibat pada kurangnya diskusi yang berarti, sebab mengekspresikan pendapat dalam kelompok besar umumnya memakan waktu, sulit dan mengakibatkan kurangnya kekompakan pada dewan direksi. Hal tersebut didukung oleh penelitian Yermacrk (1996) dan Eisenberg dkk.,(1998) menyatakan bahwa jumlah dewan direksi yang kecil meningkatkan kinerja perusahaan.

\subsubsection{Komisaris Independen (Independence Commissioners)}

Dewan komisaris independen dalam mekanisme good corporate governance berperan penting tidak hanya melihat kepetingan pemilik tetapi juga kepentingan perusahaan secara umum. Fama dan Jensen (1983) menyatakan bahwa outside director akan lebih efektif dalam memonitor manajemen selain itu outsider juga lebih banyak memberikan expert knowledge dan nilai tambah bagi perusahaan. Hal tersebut didukung oleh Boone dkk.,(2007) serta Hermalin dan Weisbach (1988) yang menyatakan bahwa outside director selain lebih efektif dalam memonitor manajemen juga merupakan sarana untuk mendisplinkan para manajer yang melakukan perilaku opportunistik terhadap kepentingannya sendiri dapat dikurangi.

\subsubsection{Struktur Kepemilikan}




\section{Jurnal Manajemen Teori dan Terapan Tahun 7. No. 3, Desember 2014}

Struktur kepemilikan merupakan suatu mekanisme tata kelola yang penting untuk mengendalikan masalah keagenan. Terutama pada lingkungan dimana tata kelola seperti market of corporate control, external auditors, rating agencies dan kerangka kerja institusi (sistem hukum dan lembaga keuangan) yang lemah. Indonesia merupakan Negara dengan sistem hukum yang lemah dan terutama control of corruption-nya yang masih rendah. Mengingat kelemahan ini struktur kepemilikan bisa menjadi cara penting untuk mengontrol masalah keagenan melalui pemilihan agen atau dewan perusahaan untuk melakukan pengelolahan dan pengawasan. Struktur dewan perusahaan merupakan hasil dari menyeimbangkan kepentingan dari stakeholders yang berbeda termasuk pemilik atau investor. Artinya, pemilik yang berbeda mungkin menunjukkan ciri-ciri yang berbeda dari perilaku dan pilihan untuk tata kelola perusahaan yang cenderung mempegaruhi struktur dewan perusahaan (Munisi dkk.,2014).

Struktur kepemilikan akan memiliki motivasi yang berbeda dalam memonitor perusahaan, manajemen dan struktur dewan. Pemilik yang berbeda mungkin menunjukkan ciri-ciri yang berbeda dari perilaku dan pilihan untuk tata kelola perusahaan yang cenderung mempegaruhi struktur dewan perusahaan (Munisi dkk.,2014). Dalam penelitian ini mencakup 3 kategori yaitu kepemilikan asing, kepemilikan manajerial, dan kepemilikan pemerintah.

\subsubsection{Kepemilikan Asing}

Kepemilikan asing adalah kepemilikan saham yang dimiliki oleh pihak pihak dari luar negeri baik individu maupun institusional (Munisi dkk.,2014). Dalam penelitian Aggarwal (2010) kepemilikan asing dalam perusahaan merupakan pihak yang concern terhadap peningkatan corporate governance seperti dengan memiliki ukuran dewan direksi yang lebih kecil dan proporsi komisaris independen yang lebih tinggi dan cenderung menerapkan praktik good corporate governance yang diterapkan di Negara asalnya dan dipromosikan ke Negara lain seperti kebutuhan untuk memiliki board size yang kecil dan dengan proporsi komisaris independen yang lebih tinggi. Di sisi lain jarak geografis mereka dengan perusahaan dan operasi perusahaan mungkin menjadi hambatan untuk terus melakukan proses monitoring yang efisien sehingga perulunya monitoring oleh komisaris independen agar menghindari terjadinya agency problem (Essen dkk.,2011).

$\mathrm{Hla}$ : kepemilikan asing berpengaruh negatif terhadap ukuran dewan direksi

$\mathrm{H} 2 \mathrm{a}$ : kepemilikan asing berpengaruh positif terhadap komisaris independen

\subsubsection{Kepemilikan Manajerial}

Kepemilikan manajerial merupakan kepemilikan saham oleh manajemen perusahaan yang diukur dengan prosentase jumlah saham yang dimiliki oleh manajemen. Menurut Munisi dkk.,(2014), besar kecilnya jumlah kepemilikan saham manajerial dalam perusahaan dapat mengindikasikan adanya kesamaan (congruance) kepentingan antara 


\section{Ella Budiarti \\ Chorry Sulistyawati}

manajemen dengan pemegang saham. Manajer yang mempunyai kepemilikan saham di perusahaan akan cenderung bertindak sesuai dengan kepentingan pemegang saham karena terdapat kesamaan kepentingan antara keduanya dan rasa memiliki perusahaan. Hal ini dapat meminimalisir terjadinya masalah keagenan (Jensen dan Meckling, 1976). Semakin besar kepemilikan manajerial dalam suatu perusahaan akan berpengaruh negatif dengan ukuran dewan direksi dan komisaris independen.

$\mathrm{HIb}$ : kepemilikan manajerial berpengaruh negatif terhadap ukuran dewan direksi

$\mathrm{H} 2 \mathrm{~b}$ : kepemilikan manajerial berpengaruh negatif terhadap komisaris independen

\subsubsection{Kepemilikan Pemerintah}

Kepemilikan pemerintah adalah jumlah saham perusahaan yang dimiliki oleh pemerintah (Munisi dkk.,2014). Perusahaan pemerintah diasumsikan untuk mengejar maksimalisasi dukungan politik. Sehingga diharapkan prosentase kepemilikan pemerintah memiliki hubungan positif dengan komisaris independen (Li, 1994). Menurut Munisi dkk.,(2014) "perusahaan dengan pemegang saham terbesarnya adalah pemerintah memiliki tata kelola perusahaan yang lemah karena lebih melayani kepentingan publik di banding kepentingan para pemegang saham". Perusahaan BUMN di Indonesia rata-rata memiliki tingkat leverage yang tinggi hal ini akan berpengaruh pada penurunan kinerja keuangan perusahaan (Triwacaningrum dan Hidayat, 2014). Keinginan publik terkadang tidak sejalan degan kepentingan pemegang saham. Hal ini akan berdampak pada berkurangnya control dari pihak pemerintah terhadap pihak manajer sebagai pengelolah perusahaan. Sehingga berpengaruh negatif dengan ukuran dewan direksi perusahaan dan perlunya pemantauan yang lebih dari komisaris independen.

$\mathrm{H} 1 \mathrm{c}$ : kepemilikan pemerintah berpengaruh negatif terhadap ukuran dewan direksi

$\mathrm{H} 2 \mathrm{C}$ : kepemilikan pemerintah berpengaruh positif terhadap komisaris independen

\section{Metode Penelitian}

\subsection{Metode Seleksi dan Pengumpulan Data}

Pada penelitian ini menggunakan populasi dari seluruh perusahaan non keuangan yang go public dan terdaftar di Bursa Efek Indonesia (BEI) periode tahun 2010-2013. Teknik Penentuan sampel dalam penelitian ini adalah dengan metode purposive sampling, yaitu suatu metode yang digunakan untuk memilih populasi yang akan dijadikan sampel dengan menggunakan pertimbangan dan batasan tertentu sehingga sampel yang dipilih relevan dengan tujuan penelitian. Berdasarkan obyek penelitian, maka penulis menetapkan kriteria pemilihan sampel yang diteliti sebagai berikut : (a) Perusahaan sampel adalah perusahaan non keuangan yang go public, yaitu pada tahun 2010-2013 masih tercatat di BEl. (b) Perusahaan sampel menerbitkan laporan keuangan tahunan perusahaan non keuangan berturut-turut pada tahun 2010-2013. (d) Perusahaan sampel yang memiliki kepemilikan 
saham mayoritas baik oleh institusi oleh asing, manajerial, dan pemerintah selama periode penelitian. 
Ella Budiarti

Chorry Sulistyawati

3.2 Jenis dan Pengukuran Variabel

Tabel 3.1

Jenis dan Pengukuran Variabel

\begin{tabular}{|c|c|c|}
\hline Variabel & Nama Variabel & Pengukuran \\
\hline \multirow{2}{*}{$\begin{array}{l}\text { Dependen: } \\
\text { Struktur Dewan } \\
\text { Perusahaan }\end{array}$} & $\begin{array}{c}\text { Ukuran Dewan } \\
\text { Direksi } \\
\text { (BOARD SIZE) }\end{array}$ & $B_{O A R D ~ S I Z E_{i t}}=$ Ln total dewan direksi $i_{i t}$ \\
\hline & $\begin{array}{c}\text { Komisaris } \\
\text { Independen } \\
\text { (INDEPENDENCE) }\end{array}$ & 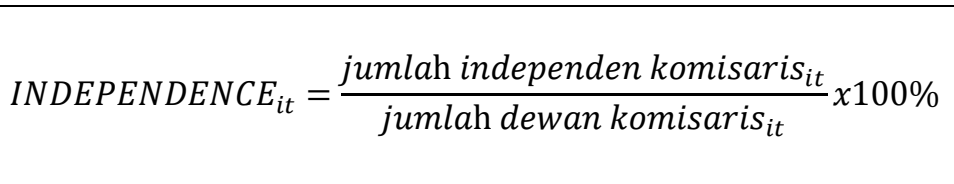 \\
\hline \multirow{3}{*}{$\begin{array}{l}\text { Independen: } \\
\text { Struktur } \\
\text { Kepemilikan }\end{array}$} & $\begin{array}{l}\text { Kepemilikan Asing } \\
\text { (FOREIGN) }\end{array}$ & 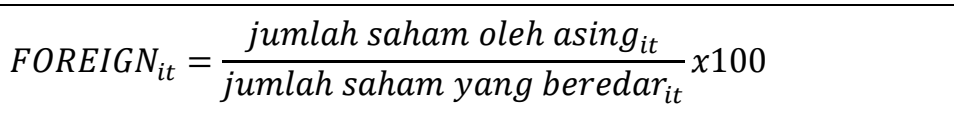 \\
\hline & $\begin{array}{l}\text { Kepemilikan } \\
\text { Manajerial } \\
\text { (MANAGERIAL) }\end{array}$ & 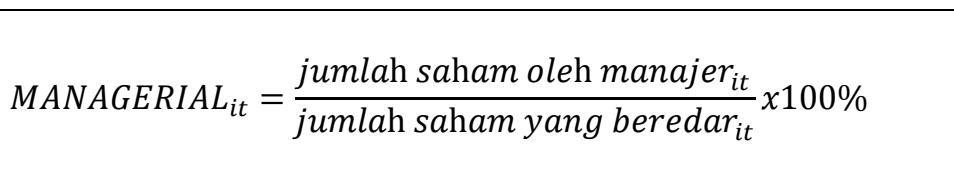 \\
\hline & $\begin{array}{c}\text { Kepemilikan } \\
\text { Pemerintah } \\
\text { (GOVERNMENT) }\end{array}$ & 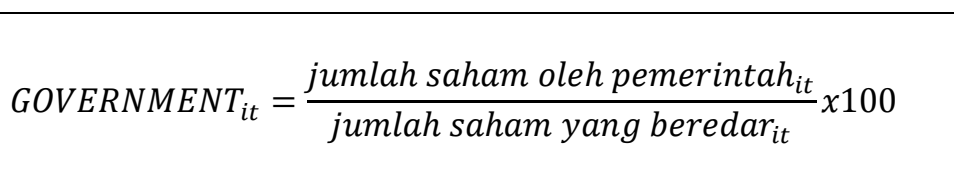 \\
\hline \multirow[t]{2}{*}{ Kontrol } & $\begin{array}{c}\text { Ukuran } \\
\text { Perusahaan } \\
\text { (SIZE) }\end{array}$ & SIZE $_{i t}=$ Ln total asset $_{i t}$ \\
\hline & $\begin{array}{l}\text { Leverage } \\
\text { (LEV) }\end{array}$ & $L E V_{i t}=\frac{\text { total utang }_{i t}}{\text { total asset }_{i t}}$ \\
\hline
\end{tabular}

\subsection{Metode Analisis Data}

Teknis analisis yang digunakan pada penelitian ini adalaha analisis regresi linier berganda dengan tingkat signifikansi $(\alpha=5 \%)$. Analisis linier berganda digunakan untuk menjawab hipotesis yang telah diajukan. Adapun model persamaan yang digunakan untuk menguji hipotesis adalah sebagai berikut:

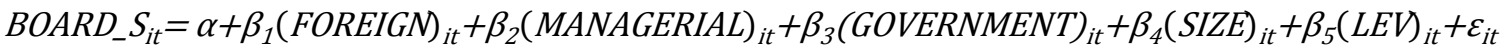

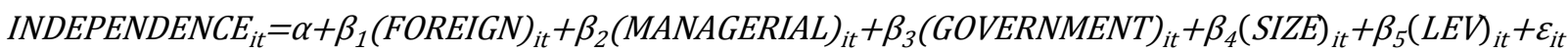

Keterangan :

BOARD_S $S_{i t} \quad=$ ukuran dewan direksi perusahaan i pada tahun ke $\dagger$

$I_{N D E P E N D E N C E} \quad=$ proporsi komisaris independen perusahaan i pada tahun ke $\dagger$

FOREIGN $_{i t} \quad=$ kepemilikan asing perusahaan i pada tahun ke $\dagger$

MANAGERIAL $_{i+} \quad=$ kepemilikan manajerial perusahaan i pada tahun ke $\dagger$ 


\section{Jurnal Manajemen Teori dan Terapan \\ Tahun 7. No. 3, Desember 2014}

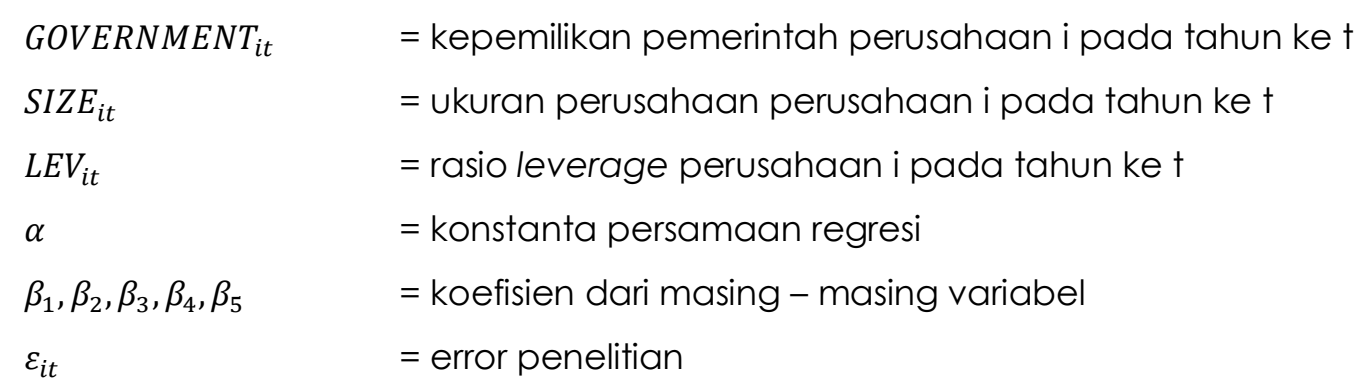

\section{Hasil dan Pembahasan}

\subsection{Hasil Analisis Penelitian}

Berdasarkan data dari variabel-variabel yang telah diukur dan setelah dilakukan uji asumsi klasik, maka dapat diperoleh hasil regresi dari keudua model sebagai berikut :

\section{Tabel 4.1}

Uji $t$

\begin{tabular}{|c|c|c|c|c|c|c|c|c|c|c|}
\hline \multirow[b]{2}{*}{ VARIABEL } & \multicolumn{5}{|c|}{ BOARD_SIZE } & \multicolumn{5}{|c|}{ INDEPENDENCE } \\
\hline & Koef. B & Nilai $t$ & Sig./2 & Hipotesis & Hasil & Koef. B & Nilai $t$ & Sig./2 & Hipotesis & Hasil \\
\hline (constant) & $-0,290$ & $-2,725$ & 0,003 & Signifikan & Signifikan & 0,156 & 3,880 & 0,000 & Signifikan & Signifikan \\
\hline FOREIGN & $-0,088$ & $-2,162$ & 0,015 & Negatif Sig. & Negatif Sig. & 0,032 & 2,078 & 0,019 & Positif Sig. & Positif Sig. \\
\hline MANAGERIAL & $-0,250$ & $-1,830$ & 0,034 & Negatif Sig & Negatif Sig & $-0,090$ & $-1,738$ & 0,042 & Negatif Sig & Negatif Sig \\
\hline GOVERNMENT & $-0,066$ & $-0,755$ & 0,225 & Negatif Sig. & Negatif Tidak Sig. & $-0,093$ & $-2,844$ & 0,003 & Positif Sig. & Negatif Sig. \\
\hline SIZE & 0,127 & 17,980 & 0,000 & Positif Sig. & Positif Sig. & 0,015 & 5,484 & 0,000 & Positif Sig. & Positif Sig. \\
\hline LEV & $-0,025$ & $-1,047$ & 0,148 & Positif Sig. & Negatif Tidak Sig. & 0,022 & 2,461 & 0,007 & Positif Sig. & Positif Sig. \\
\hline R Square & \multicolumn{5}{|l|}{0,344} & \multicolumn{5}{|l|}{0,064} \\
\hline $\begin{array}{l}\text { Adjusted R } \\
\text { square }\end{array}$ & \multicolumn{5}{|l|}{0,340} & \multicolumn{5}{|l|}{0,058} \\
\hline Uji F & \multicolumn{5}{|l|}{79,620} & \multicolumn{5}{|l|}{10,426} \\
\hline Signifikasi & \multicolumn{5}{|l|}{0,000} & \multicolumn{5}{|l|}{0,000} \\
\hline
\end{tabular}

Sumber: Data hasil output SPSS Statistics 19

* Signifikansi jika sig. $t<0.5$

Nilai konstanta pada model regresi yang pertama adalah -0,290. Hal ini menunjukkan besarnya ukuran dewan direksi perusahaan (BOARD_S) pada perusahaan non keuangan di Bursa Efek Indonesia selama periode 2010-2013, yang tidak dipengaruhi oleh kepemilikan asing, kepemilikan manajerial, kepemilikan pemerintah, ukuran perusahaan dan leverage. Dan nilai konstanta pada model regresi yang pertama adalah 0,156 . Hal ini menunjukkan besarnya komisaris independen (INDEPENDENCE) pada perusahaan non keuangan di Bursa Efek Indonesia selama periode 2010-2013, yang tidak dipengaruhi oleh kepemilikan asing, kepemilikan manajerial, kepemilikan pemerintah, ukuran perusahaan dan leverage. 


\section{Ella Budiarti \\ Chorry Sulistyawati}

Koefisien regresi penelitian menunjukkan tanda yang bervariasi, yaitu positif dan negatif. Koefisien bertanda positif menunjukkan perubahan yang searah antara variabel bebas terhadap variabel terikat, sedangkan koefisien yang bertanda negatif menunjukkan arah perubahan yang berlawanan antara variabel bebas terhadap variabel terikat. Berdasarkan tabel 4.1 dapat disimpulkan bahwa struktur kepemilikan berpengaruh signifkan terhadap struktur dewan perusahaan. Untuk variabel dependen yang pertama yaitu ukuran dewan direksi (BOARD_SIZE) diperoleh hasil bahwa kepemilikan asing dan manajerial berpengaruh negatif signifikan sedangkan kepemilikan pemerintah berpengaruh negative tidak signifikan. Dan untuk variabel dependen yang kedua yaitu komisaris independen (INDEPENDENCE), diperoleh hasil bahwa kepemilikan manajerial dan pemerintah berpengaruh negatif signifikan, sedangkan kepemilikan asing berpengaruh positif signifikan. Sedangkan untuk variabel kontrol SIZE berpengaruh positif signifikan terhadap struktur dewan perusahaan sedangkan leverage berpengaruh tidak signifikan terhadap ukuran dewan direksi dan positif signifikan terhadap komisaris independen

Nilai R2 sebesar 0,344 mengindikasikan bahwa 34,4\% variasi BOARD SIZE dapat dijelaskan oleh variasi dari variabel FOREIGN, MANAGERIAL, GOVERNMENT, SIZE, dan LEV sedangkan sisanya sebesar 0,656 atau sebesar 65,6\% dijelaskan oleh variabel lain yang tidak digunakan dalam penelitian. Sementara koefisien determinasi untuk model regresi yang kedua dapat dilihat pada tabel 4.3 bahwa Nilai R2 sebesar 0,064 mengindikasikan bahwa 6,4\% variasi INDEPENDENCE dapat dijelaskan oleh variasi dari variable FOREIGN, MANAGERIAL, GOVERNMENT, SIZE, dan LEV sedangkan sisanya sebesar 0,936 atau sebesar $93,6 \%$ dijelaskan oleh variabel lain yang tidak digunakan dalam penelitian.

\subsection{Pembahasan}

Dari model regresi yang pertama menunjukkan bahwa variabel dari struktur kepemilikan berpengaruh secara signifikan terhadap ukuran dewan direksi perusahaan. Struktur kepemilikan yang terdiri dari kepemilikan asing, kepemilikan manajerial, dan kepemilikan pemerintah memiliki arah negatif sesuai Hla, Hlb, dan Hlc. Hal ini berarti bahwa semakin tinggi kepemilikan asing, kepemilikan manajerial, dan kepemilikan pemerintah suatu perusahaan, maka semakin kecil ukuran dewan direksi yang dimiliki.

Dari model regresi yang kedua menunjukkan bahwa semua variabel dari struktur kepemilikan berpengaruh secara signifikan terhadap proporsi komisaris independen perusahaan. kepemilikan manajerial memiliki arah negatif sesuai dengan hipotesis 2c. Kepemilikan asing juga sesuai dengan hipotesis $2 b$ yaitu memiliki arah yang sama positif. Sedangkan kepemilikan pemerintah memiliki arah yang tidak sesuai dengan hipotesis 2c. Hal ini berarti bahwa semakin tinggi kepemilikan manajerial dan kepemilikan pemerintah suatu perusahaan, maka semakin kecil proporsi komisaris independen yang dimiliki Sedangkan semakin besar kepemilikan asing suatu perusahaan, maka semakin besar pula 


\section{Jurnal Manajemen Teori dan Terapan \\ Tahun 7. No. 3, Desember 2014}

proporsi komisaris independen yang dimiliki. Berikut ini pembahasan dari masing-masing struktur kepemilikan terhadap struktur dewan perusahaan :

\subsubsection{Kepemilikan Asing}

Kepemlikan asing memiliki pengaruh negatif signifikan terhadap ukuran dewan direksi perusahaan. Hasil ini sesuai dengan Munisi dkk., (2014) yang menyatakan bahwa kepemilikan asing memiliki pengaruh negatif dengan ukuran dewan hal ini dikarenakan investor asing memiliki corporate governance yang baik mereka cenderung menerapkan praktik good corporate governance yang diterapkan di Negara asalnya dan dipromosikan ke Negara lain seperti kebutuhan untuk memiliki board size yang kecil dan dengan proporsi komisaris independen yang lebih tinggi.

Kepemilikan asing juga memiliki pengaruh positif signifikan terhadap proporsi komisaris independen. Hasil ini sesuai dengan penelitian yang dilakukan oleh Munisi dkk., (2014) dan Aggarwal dkk., (2010) Kepemilikan institusional asing meningkatkan kemungkinan memiliki dewan mayoritas komisaris independen, yang ukurannya sesuai, dan hal itu tidak mengadopsi ketentuan dewan yang berubah-ubah. Essen dkk.,(2011) menunjukkan bahwa pemilik asing memiliki pengaruh yang cukup untuk meningkatkan kemampuan pemantauan mereka dengan mendirikan praktik tata kelola yang baik di perusahaan-perusahaan yang mereka tanamkan investasi. Di sisi lain jarak geografis mereka dengan perusahaan dan operasi perusahaan mungkin menjadi hambatan untuk terus melakukan proses monitoring yang efisien sehingga perulunya monitoring oleh komisaris independen agar menghindari terjadinya agency problem.

\subsubsection{Kepemilikan Manajerial}

Kepemilikan manjerial memiliki pengaruh negatif signifikan terhadap ukuran dewan direksi. Hasil ini sesuai dengan penelitian yang dilakukan oleh Munisi dkk., (2014) dan Mak \& Li (2001). Jensen dan Meckling (1976) menemukan bahwa kepemilikan manajerial berhasil menjadi mekanisme pengurang masalah keagenan dari manajer dengan menyelaraskan kepentingan-kepentingan manajer dengan pemegang saham. Hal ini berarti proses monitoring yang dibutuhkan oleh pemegang saham lebih sedikit untuk itu jumlah dewan direksi yang dibutuhkan juga lebih sedikit karena adanya kesamaan tujuan antara pemegang saham dan manajemen.

Semakin banyak kepemilikan manajerial dalam sebuah perusahaan mengindikasikan kecilnya dewan direksi dan komisaris serta komisaris independen yang dibutuhkan oleh perusahaan. Karena kesamaan tujuan antara manajerial dengan pemegang saham menghindarkan manajer dari perilaku yang mementingkan kepentingan mereka sendiri.

\subsubsection{Kepemilikan Pemerintah}

Kepemilikan pemerintah memiliki pengaruh negatif tidak signifikan terhadap ukuran dewan direksi perusahaan. Hasil penemuan ini sesuai dengan penelitian yang dilakukan Mak 


\section{Ella Budiarti \\ Chorry Sulistyawati}

\& Li (2001). Menurut Mak \& Li (2001) hal ini dikarenakan perusahaan dengan pemegang saham terbesarnya adalah pemerintah memiliki tata kelola perusahaan yang lemah karena lebih melayani kepentingan publik di banding kepentingan para pemegang saham. Keinginan publik terkadang tidak sejalan degan kepentingan pemegang saham. Hal ini akan berdampak pada berkurangnya control dari pihak pemerintah terhadap pihak manajer sebagai pengelolah perusahaan sehingga semakin tinggi prosentase kepemilikan pemerintah maka semakin sedikit jumlah dewan direksi dan komisaris independen yang dimiliki perusahaan.

Selain sebagai pemegang saham pengendali dalam perusahaan pemerintah di Indonesia juga berfungsi sebagai regulator yang berwenang mengatur perusahaan melalui Kementrian BUMN. Sehingga fungsi pengawasan perusahaan dengan kepemilikan pemerintah yang besar tidak hanya dilakukan oleh dewan komisaris saja tetapi juga didukung dari berbagai badan pengawasan yang khusus untuk perusahaan (BUMN). Kemungkinan hal inilah yang mengurangi permintaan pengawasan dari komisaris independen.

\subsubsection{Pengaruh Size terhadap Struktur Dewan Perusahaan}

Dari model regresi yang pertama dan kedua menunjukkan bahwa ukuran perusahaan (size) memiliki pengaruh yang signifikan terhadap ukuran dewan direksi dan proporsi komisaris independen sebuah perusahaan. dan hasil keduanya juga menunjukkan arah yang positif artinya semakin besar ukuran perusahaan maka jumlah dewan direksi perusahaan dan proporsi dari komisaris independen yang dimiliki juga akan semakin besar.

Hasil ini sesuai dengan penelitian yang dilakukan oleh Mak \& Li (2001), Essen dkk., (2011), Al Naif (2013), yang menunjukkan bahwa ukuran perusahaan berpengaruh positif signifikan terhadap struktur dewan. Dan dalam penelitian Munisi., dkk (2014) ukuran perusahaan berpengaruh positif signifikan terhadap ukuran dewan, perusahaan yang besar membutuhkan jumlah dewan yang besar pula untuk mengawasi dan menasehati. Perusahaan yang besar mencerminkan biaya agensi yang lebih besar. Mereka membutuhkan lebih banyak independen komisaris untuk mengurangi masalah keagenan.

\subsubsection{Pengaruh Leverage terhadap Struktur Dewan Perusahaan}

Dari model regresi yang pertama dan kedua menunjukkan bahwa leverage tidak memiliki pengaruh terhadap ukuran dewan direksi dan signifikan terhadap proporsi komisaris independen sebuah perusahaan. Dan hasilnya menunjukkan bahwa semakin besar leverage perusahaan maka jumlah dewan direksi perusahaan akan semakin berkurang dan proporsi komisaris independen bertambah.

Hasil ini sesuai dengan penelitian Munisi dkk., (2014) dan Essen dkk.,(2011) yang menemukan hubungan negatif antara leverage dengan board size dan positif terhadap proporsi komisaris independen. Perusahaan dengan tingkat leverage yang tinggi akan 


\section{Jurnal Manajemen Teori dan Terapan \\ Tahun 7. No. 3, Desember 2014}

bergantung pada sember daya keuangan eksternal, sehingga memerlukan lebih banyak saran dan monitoring dari luar perusahaan agar lebih efektif. Tidak adanya pengaruh leverage terhadap ukuran dewan direksi perusahaan karena leverage dapat memberikan sinyal kepada investor bahwa perusahaan mempunyai kredibilitas yang tinggi dari kreditor untuk menggunakan dana pinjaman bagi kepentingan usaha yang prospektif, yang pada akhirnya juga akan meningkatkan laba. Namun pada kondisi tertentu, tingkat leverage yang tinggi juga dapat mengindikasikan tingginya risiko kebangkrutan yang muncul akibat jika perusahaan tidak dapat memenuhi kewajiban jangka panjangnya (Triwacaningrum dan Hidayat, 2014).

\section{Kesimpulan}

Berdasarkan hasil pengujian dan analisis yang telah dilakukan dalam penelitian ini dapat disimpulkan bahwa :

1. Kepemilikan asing di Indonesia berpengaruh negatif signifikan terhadap Ukuran dewan direksi perusahaan dan memiliki pengaruh positif signifikan terhadap proporsi komisaris independen.

2. Kepemilikan manajerial di Indonesia berpengaruh negatif signifikan terhadap ukuran dewan direksi perusahaan dan proporsi komisaris independen.

3. Kepemilikan pemerintah di Indonesia berpengaruh negatif tidak signifikan terhadap ukuran dewan direksi perusahaan dan negative signifikan terhadap proporsi komisaris independen.

4. Variabel kontrol ukuran perusahaan berpengaruh positif signifikan dengan ukuran dewan direksi perusahaan dan proporsi komisaris independen. Sedangkan leverage tidak berpengaruh terhadap ukuran dewan direksi perusahaan dan positif signifikan terhadap proporsi komisaris independen 


\section{Ella Budiarti \\ Chorry Sulistyawati}

\section{Daftar Pustaka}

Aggarwal, Reena.,dkk. 2010. Does Governance Travel Around The World? Evidence From Institusional Investors. Joournal of Financial Economics.

Alnaif, Khaled LK. 2014. Determinants of The Size of Board of Directors : Evidence From Jordanian Corporation. Journal of Finance and Accounting. 5(8) : 54-63.

Alijoyo, Antonius dan Subarto Zaini. 2004. Komisaris Independen : Penggerak Praktik GCG di Perusahaan. Jakarta : PT. Indeks Kelompok Gramedia

Amiruddin, Umar. 2005. Struktur Kepemilikan, Nilai Perusahaan, dan Corporate Governance : Suatu Perspektif Keagenan. Surabaya : Airlangga University Press.

Baird, M. 2000. The Proper governance of Companies Will become as Crucial to The World Economy as The Proper Governing of Countries, 'Paper.

Bennedsen, Morten. 2002. Why do Firms Have Boards?. Working Paper, JEL Classification. 114.

Boone, Audra L dkk. 2007. The Determinants of Corporate Board Size And Composition : An Empirical Analysis. Journal of Financial Economics. Vol 85 : 66-101

Budiarti, Ella dan Chorry Sulistyowati, 2015. Struktur Kepemilikan dan Struktur Dewan Perusahaan, Program Studi S1 Manajemen Unversitas Airlangga, 96.

Dalton, Dan R dkk. 2007. The Fundamental Agency Problem and Its Mitigation: Independence, Equity, and The Market For Corporate Control. The Academy of Management Annals. $3: 1-64$.

Deng, Xiaolan dan Zongjun Wang. 2006. Ownership Structure and Financial Distress: Evidence from Public Listed Companies in China. International Journal Management. Vol. 23, No.3:468-502.

Destriana, Nicken. 201 1. Masalah dan Biaya Keagenan. Media Bisnis

Eisenberg, Theodore dkk.1998. Larger Board Size and Decreasing Firm Valve in small Firms. Journa of Financial Economics. Vol $48: 35-54$.

Essen, Marc Van dkk. 2011. Corporate Boards and The Performance of Asian Firms:A MetaAnalysis.

Faizal. 2004. Analisis Agency Costs, Struktur Kepemilikan dan Mekanisme Corporate Governance. Simposium Nasional Akuntansi VII. Denpasar Bali.

Fama, Eugene F., dan Michael C. Jensen. 1983.Separation of Ownership and Control, Journal of Law and Economics. 26: 301-325.

Germaint, Laurent dkk, 2014. Corporate Governance Reform In Malaysia: Board Size, Independence and Monitoring. Journal of Economics and Business. 75: 126-162.

Ghozali, Imam. 2005. Aplikasi Analisis Multivariate Dengan SPSS. Edisi Ketiga. Semarang. Badan Penerbit Undip. 


\section{Jurnal Manajemen Teori dan Terapan \\ Tahun 7. No. 3, Desember 2014}

Hermalin, B dan Weisbach, M.S, 1991. The Effects of Board Composition and Direct Incentives on Firm Performance. Financial Management. Vol.20: 101-112.

Jensen, M., dan Meckling, W. 1976. Theory of The firm: Managerial Behavior, Agency Costs and Ownership Structure. Journal of Financial Economics, 3: 305-360.

Jensen, M. 1993. The Modern Industrial Revolution, Exit And The Failure Of Internal Control Systems. Journal of Finance 48: 831-880.

Kaufmann, Daniel dkk. 2010. The Worldwide Governance Indicators: Methodology and Analytical Issues, (online), (http://info.worldbank.org/governance/wgi/index.aspx\#reports, diakses 5 Oktober 2014).

Lehn, K.M Patro,S. dan Zhao M. 2009. Determinants of The Size And Composition of US Corporate Boards. Journal of Financial Management. Vol 4:747-780.

Li, Jiatao. 1994. Ownership Structure and Board Composition :Multi-Country Test Of Agency Theory Predictions. Jurnal Managerial and Decision Economics. 15 (4): 359-368.

Linck, James S. 2008. The determinants of board structure. Journal of Financial Economics 87 (9): 308-328.

Lipton, M dan Lorsch J. 1992. A Modest Proposal for Improved Corporate Governance Business Lawyer. Vol 48: 59-77.

Mak, Y.T dan Yuan Li. 2001. Determinants Of Corporate Ownership and Board Structure: Evidence From Singapore. Jurnal of Corporate Finance, 7(6) : 235-256.

Monem, Reza M. 2013. Determinants of board structure: Evidence from Australia. Journal of Accounting and Economics. 9(2): 33-49

Munisi, Gibson dkk. 2014. Corporate Boards and Ownership Structure : Evidence from SubSaharan Africa. Jurnal Bisnis Internasional, 23(1): 785-796.

NCCG. 2001. Pedoman Good Corporate Governance.

OECD. 2004. OECD Principles of Corporate Governance.

Onetto, Andress E. 2007. Agency Problems and The Board of Directors. Journal of Internasional Banking and Financial Law, 414-417.

Rifai, Badriyah. 2009.Peran Komisaris Independen dalamMewujudkan Good Corporate Governance di Perusahaan Publik. Jurnal Hukum, 3(7) : $396-412$.

Sari, Derry Permata dan Bahtiar Usman. 2014. Pengaruh Board Structure dan Ownership Structure terhadap Firm Performance Pada Perusahaan Manufaktur yang terdaftar di Bursa Efek Indonesia. Jurnal Manajemen Fakultas Ekonomi. Vol 1 : 44-69.

Sudana, I Made. 2011. Manajemen Keuangan Perusahaan : Teori Dan Praktik. Jakarta: Erlangga 


\section{Ella Budiarti}

\section{Chorry Sulistyawati}

Sudarmadji, Adi M dan Sularto, Lana. 2007. Pengaruh Ukuran Perusahaan, Profitabilitas, Leverage dan Tipe kepemilikan Perusahaan terhadap Luas Voluntary Discloure Laporan Keuangan Tahunan. Proceeding PESAT, Volume 2.

Syafruddin ,Muchamad dan Aga Nugroho S. 2012. Pengaruh Struktur Kepemilikan Dan Mekanisme Corporate Governance Terhadap Biaya Keagenan.(Online). (http://ejournal-sl.undip.ac.id diakses tanggal 19 november 2014).

Triwacananingrum, Wijaya dan Widi Hidayat. 2014. Pengaruh Kinerja Sosial dan Financial Leverage terhadap Kinerja Keuangan dengan Klasifikasi Perusahaan Sebagai Variabel Moderator Pada BUMN. Jurnal Ekonomi dan Bisnis, 150-158.

Yermack, David. 1996. Higher Market Valuation of Companies with a Small Board of Directors. Journal of Financial Economics. Vol $40: 185-211$.

www.bapepam.go.id

www.idx.co.id 
Jurnal Manajemen Teori dan Terapan Tahun 7. No. 3, Desember 2014 